\title{
Online Representation of Sustainable City Initiatives in Africa: How Inclusive?
}

\author{
Ton Dietz
}

\begin{abstract}
Africa's rapid population growth, and even more rapid urbanisation, creates serious sustainability challenges. Like many cities in other parts of the world, African cities try to become 'green', and promote change in urban design and lifestyles to encourage more sustainable living. Many of these initiatives are supported by international agencies and illustrated on agency websites. Studying these websites, we try to answer three related questions dealing with the inclusivity of those initiatives: the geographical coverage (which cities?), the thematic coverage (how 'holistic'?) and the social inclusivity (how inclusive in terms of social focus?). Both scholars and practitioners should become more inclusive in their approaches to sustainable cities in Africa.
\end{abstract}

'The challenge of achieving sustainable urban development will be particularly formidable in Africa.'

COHEN 2006, 63

Many scholars still regard Africa as a rural continent, with few and relatively unimportant megacities, compared to Asia, the Americas and Europe. In the world's leading textbooks on urban geography, Africa has received very limited attention so far (e.g. Kaplan and Holloway, 2014; Knox and McCarthy, 2012; Hall and Barrett, 2012; Pacione, 2009). Things are changing, though, because Africa is changing, and it is changing rapidly, even if its demographic transition lags behind compared to all other continents. The lowering of Africa's fertility levels started only in the 1980 s and demographers expect that Africa will have completed its demographic transition only in 2100. In the meantime, Africa's population has grown from 300 million in 1960 to more than 1.2 billion in 2015 , while it is expected to grow to between 3.3 and 5.6 billion in 2100 (with 4.4

(C) TON DIETZ, 2018 | DOI:10.1163/9789004387942_007

This is an open access chapter distributed under the terms of the prevailing CC-BY-NC License at the time of publication. 
billion given as the median figure). High fertility levels play a major role here, but improved health care, food availability and hygiene, which together result in much higher life expectancy figures, play a role as well. A rapidly growing, relatively very young and possibly very vibrant urban African population will become a major demographic factor in the world. The demographic expectation is that Africa will have close to 40 per cent of the world's population by 2100, probably more than Asia, and more than five times the figure for Europe (see Heilig's website www.demographics.at).

Also in global terms Africa's cities are becoming relatively more important. In a comparative study, Barney Cohen (Cohen, 2006), the former Chief of the Population Studies Branch of the United Nations in New York, presents interesting data, which we summarise in Table 6.1.

Cohen noted with concern that around the year 2000 many urban Africans lacked piped water, flush toilets and electricity in their urban homes, particularly in the smaller urban centres: in sub-Saharan Africa 50 per cent of the urban households lacked these amenities in cities with fewer than 100,000 inhabitants, 40 per cent in cities of between 100,000 and 500,000 inhabitants, 35 per cent in cities of half a million to a million inhabitants, and 22 per cent in cities of more than one million inhabitants, unlike for instance North Africa (where these figures were only 5, 2, 4 and 6 per cent, respectively) or all other parts of the world (including Asia), where these figures were all much lower than in Africa. Cohen writes (2006, 75 and 77): There is an urgent need to build and support the capacity of local governments to manage the environmental and social service problems that accompany rapid urban growth'. He adds: 'An

TABLE 6.1 Africa's cities in world perspective

\begin{tabular}{lcccc}
\hline & $\begin{array}{c}\text { No. of cities } \\
\text { 1 million in } \\
\text { Africa }\end{array}$ & $\begin{array}{c}\text { Total urban } \\
\text { population in } \\
\text { Africa }\end{array}$ & $\begin{array}{c}\text { African urban } \\
\text { population as } \% \\
\text { of world urban } \\
\text { population }\end{array}$ & $\begin{array}{c}\text { pop African } \\
\text { potion in } \\
\text { cities }\end{array}$ \\
\hline 1950 & 2 & 33 & 5 & 15 \\
1975 & 8 & 103 & 7 & 25 \\
2000 & 35 & 295 & 10 & 37 \\
2015 & 61 & 481 & 12 & 41 \\
2030 (pred.) & & 748 & 15 & 54 \\
\hline
\end{tabular}

SOURCES: COHEN (2006); DATA FOR 1950, 1975, 2000 AND 2030 PREDICTION: PP. 70, 71 AND 75. FOR 2015: CALCULATED FROM WORLD BANK DATA AND STATISTICS TIMES 
essential feature of current African urbanisation, is that unlike cities in much of Asia and Latin America, urbanization appears to have become decoupled from economic development. The vast majority of African cities are economically marginalized in the new global economy and most African cities are growing despite poor macroeconomic performance and without significant direct foreign investment'. This was written in the middle of that first decade of the new millennium, and based on statistics from around 2000, when it was not yet clear that Africa was about to enter an era of rapid economic growth that would last until 2015 and during which African cities (although not all) did become engines of rapid economic growth, and of social vitality. But it is obviously true, and it will remain true for many decades, that managing African cities, also in terms of sustainability, will be one of the major challenges of the twenty-first century.

In 2012, the African Studies Centre in Leiden produced a thematic map of 'Africa: From a Continent of States to a Continent of Cities' (Dietz et al., 2012). Table 6.2 provides an update of this thematic map for all urban agglomerations with currently more than two million inhabitants, based on data from the website citypopulation.de. ${ }^{1}$ Other sources use other definitions of urban areas or cities, and arrive at different, often lower figures. The most important of these are the statistical sections in the UN-Habitat 'State of the African City' Reports (e.g. the one for 2014) and the World Bank data on urbanisation, the annual World Urbanization Prospect reports (United Nations Department of Economic and Social Affairs, 2014). For the thematic map, and for Table 6.2 of this chapter, we used the agglomeration assessments, because they give a more useful indication of built-up areas.

In total, Africa in early 2016 had 32 urban agglomerations with more than two million inhabitants. Of Africa's current 54 states, 36 have, today, at least one urban agglomeration with more than one million inhabitants, and the total number of African multi-million urban areas is 61. More than 150 million of Africa's 1.2 billion people now live in these multi-million agglomerations, and soon there will be many more.

\section{Online Representation of Sustainable City Initiatives in Africa}

Urban areas in Africa have different political and economic functions (e.g. as capital cities or harbour cities) and their locational characteristics also differ: coastal or inland; in dry lands or more humid climatological conditions.

1 More particularly the page 'Major Agglomerations of the World', http://www.citypopulation .de/world/Agglomerations.html (see Brinkhoff's website). 
TABLE 6.2 Africa's major urban agglomerations in $2016^{\mathrm{a}}$

\begin{tabular}{|c|c|c|}
\hline Urban agglomeration & Country & $\begin{array}{l}\text { Population in millions } \\
\qquad(\mathbf{1 . 1 . 2 0 1 6 )}\end{array}$ \\
\hline Lagos & Nigeria & 17.1 \\
\hline Cairo & Egypt & 16.8 \\
\hline Johannesburg & South Africa & 13.4 \\
\hline Kinshasa & DR Congo & 10.6 \\
\hline Luanda & Angola & 6.8 \\
\hline Khartoum & Sudan & 5.6 \\
\hline Dar es Salaam & Tanzania & $5 \cdot 3$ \\
\hline Nairobi & Kenya & $5 \cdot 2$ \\
\hline Alexandria & Egypt & 5.2 \\
\hline Abidjan & Côte d'Ivoire & 5.1 \\
\hline Accra & Ghana & 4.6 \\
\hline Casablanca & Morocco & 4.2 \\
\hline Cape Town & South Africa & 4.1 \\
\hline Kano & Nigeria & 4.1 \\
\hline Algiers & Algeria & $3 \cdot 7$ \\
\hline Addis Ababa & Ethiopia & $3 \cdot 5$ \\
\hline Dakar & Senegal & $3 \cdot 3$ \\
\hline Durban & South Africa & 3.2 \\
\hline Ibadan & Nigeria & 3.2 \\
\hline Kampala & Uganda & 3.0 \\
\hline Bamako & Mali & 3.0 \\
\hline Abuja & Nigeria & 2.8 \\
\hline Douala & Cameroon & 2.8 \\
\hline Yaoundé & Cameroon & 2.7 \\
\hline Kumasi & Ghana & 2.7 \\
\hline Tunis & Tunisia & 2.5 \\
\hline
\end{tabular}




\begin{tabular}{llc}
\hline Urban agglomeration & Country & $\begin{array}{c}\text { Population in millions } \\
(\mathbf{1 . 1 . 2 0 1 6})\end{array}$ \\
\hline Harare & Zimbabwe & 2.3 \\
Lusaka & Zambia & 2.3 \\
Antananarivo & Madagascar & 2.2 \\
Conakry & Guinea & 2.2 \\
Maputo & Mozambique & 2.2 \\
Ouagadougou & Burkina Faso & 2.1 \\
Port Harcourt & Nigeria & 2.1 \\
\hline
\end{tabular}

a According to Brinkhoff's website, 'Urban agglomerations include a central city and neighboring places mostly linked by (more or less) continuously built-up areas. Some agglomerations have more than one central city'. Compared to the 2012 data from the same source, two towns in Somalia (Mogadishu and Hargeisa) dropped below the two million threshold used here, while Pretoria had become part of Greater Johannesburg. Bamako, Maputo, Antananarivo, Lusaka, Yaoundé, Ouagadougou, Conakry and Port Harcourt had all crossed the two million threshold in those few years.

SOURCE: BRINKHOFF T., HTTP://WWW.CITYPOPULATION.DE/WORLD/AGGLOMERATIONS. HTML

Environmental conditions may determine perceptions of sustainability: coastal areas are prone to storms, flooding and sea level rise (UN-Habitat, 2014), while dry lands can face droughts and water stress. Political and economic conditions may determine the urge of national governments to deal with popular concerns, including living conditions, some of which are related to sustainability issues. So it is wise to look at the characteristics of cities if one wants to get an idea of their environmental challenges, and if one wants to understand the diversity of sustainable city initiatives. In this second part of the chapter we will present various representations of Africa's sustainability experiences on relevant Internet sites. We will look at these representations, and ask ourselves three related questions, all dealing with the inclusiveness of sustainability: (1) what is the geographical coverage of these sustainable city initiatives (which cities are the 'favourites' of the various 'African sustainable cities' websites, and which ones are not?), (2) what is the thematic coverage? (how 'holistic' is the representation; what themes get most attention?), and (3) how do these websites present the social inclusiveness of 'their' sustainable city initiatives? 
One of the most informative overviews of sustainable city initiatives in Africa is given in a report by The Economist Intelligence Unit (EIU) (supported by Siemens) in 2010, the African Green City Index. Following comparable assessments of cities in Europe, Latin America, Asia, the USA and Canada, the Unit carried out an extensive survey of 15 major African cities, and tried to apply eight different main assessment criteria together with 25 sub-criteria (EIU, 2011, 31; Table 6.3 of this chapter presents the results). Some cities could not be included because of a lack of data; for example, Kinshasa, Khartoum and Algiers were explicitly mentioned and data availability and reliability was a major problem in almost all other cities as well.

For the fifteen major African cities selected by The Economist Intelligence Unit, the results of the assessment of environmental performance show major differences. The assessment was based on a combination of EIU judgements, Siemens judgements, and judgements made by a panel of six external, independent experts, the last of which, however, did not include a single African (see EIU, 2011, 4). Table 6.4 gives the details, combining scores on a five-point scale (from ++ to --) with major and minor highlights mentioned in the text ( $\mathrm{H}$ and $\mathrm{h}$ ). Highlights show the most important recent initiatives (that is, before 2010) undertaken by city governments in any of the eight categories of 'major issues'.

Three South African cities lead the assessment, and they share eight of the 24 highlighted examples among them, including attention to Cape Town's energy policy, Durban's overall environmental governance, and Johannesburg's efforts to improve the city's land use in a sustainable way. Two North African cities (Casablanca and Tunis) follow, as does Accra in Ghana, which gets a major highlight for its water and sanitation approaches, and a minor one for environmental governance. These six cities get a positive overall assessment. Five African cities receive an average judgement: one in West Africa (Lagos, with a special highlight for its waste management approaches), two in Egypt (Cairo, with a special highlight for its transport approach and Alexandria, with a special highlight for water and sanitation policies), one in the Horn of Africa (Addis Ababa) and one in South Africa (Pretoria/Tshwane). Four cities get an overall negative assessment (Nairobi and Luanda) or even an overall very negative assessment (Dar es Salaam and Maputo). For Luanda, Nairobi and Maputo the report highlights some attempts to develop better environmental governance and for Dar es Salaam and Maputo minor highlights are presented regarding water and sanitation initiatives.

The scores on energy and $\mathrm{CO}_{2}$ reflect the major differences in energy consumption and energy composition on the continent, on the one hand, with 
TABLE 6.3 EIU criteria for the African Green City Index

Issues (main Sub-criteria
criteria)

Energy and $\mathrm{CO}_{2}$ Percentage of households with access to electricity. Electricity consumption per capita

$\mathrm{CO}_{2}$ emissions from electricity

Measure of a city's efforts to reduce carbon emissions

Land Use Population density

Percentage of population living in informal settlements

Green spaces per capita (sum of all public parks, recreation areas and 'greenways')

Land use policy

Transport Public transport network: length of superior transport network (bus rapid transit, trams, light rail and 'subway'), and length of mass transport network

Urban mass transport policy

Congestion reduction policy

Waste Total annual volume of waste generated by the city

Waste collection and disposal policy

Waste recycling and reuse policy

Water Access to potable waterWater consumption per capita

Water system leakages

Water quality policy

Water sustainability policy

Sanitation Population with access to improved sanitation (share of the total population either with sanitation connections to sewerage or access to on-site sources)

Sanitation policy: measure of a city's efforts to reduce pollution associated with inadequate sanitation

Air Quality Clean air policy: measure of a city's efforts to reduce air pollution

Environmental Environmental management: measure of the extensiveness of

Governance environmental management undertaken by the city

Environmental monitoring: measure of the city's efforts to monitor its environmental performance

Public participation: measure of the city's efforts to involve the public in environmental decision-making.

SOURCE: EIU $(2011,31)$ 
TABLE 6.4 Assessment of environmental performance in 15 major African cities

\begin{tabular}{|c|c|c|c|c|c|c|c|c|c|}
\hline City & $\begin{array}{l}\text { Energy } \\
\text { and } \mathrm{CO}_{2}\end{array}$ & $\begin{array}{l}\text { Land } \\
\text { use }\end{array}$ & Transport & Waste & Water & Sanitation & Air quality & $\begin{array}{l}\text { Environmental } \\
\text { governance }\end{array}$ & Total \\
\hline Cape Town & $-\mathrm{H}$ & ++ & + & $+\mathrm{h}$ & $+\mathrm{h}$ & o & + & + & $+/ 6$ \\
\hline Durban & - & + & + & $+\mathrm{h}$ & $+\mathrm{h}$ & + & + & $+\mathrm{H}$ & $+/ 6$ \\
\hline Johannesburg & + & $+\mathrm{H}$ & $+\mathrm{h}$ & o & o & o & + & + & $+/ 5$ \\
\hline Casablanca & + & $+\mathrm{h}$ & o & o & + & + & + & o & $+/ 5$ \\
\hline Accra & $+\mathrm{h}$ & o & - & o & $\mathrm{oH}$ & + & + & $++\mathrm{h}$ & $+/ 4$ \\
\hline Tunis & - & oh & $+\mathrm{h}$ & + & o & + & + & o & $+/ 3$ \\
\hline Lagos & $++\mathrm{h}$ & - & oh & $+\mathrm{H}$ & o & o & o & o & $0 / 2$ \\
\hline Addis Ababa & ++ & $+\mathrm{h}$ & - & o & + & o & - & - & $0 / 1$ \\
\hline Alexandria & o & - & o & $++\mathrm{h}$ & $-\mathrm{H}$ & o & o & o & o/o \\
\hline Cairo & o & o & $+\mathrm{H}$ & - & oh & o & o & o & $0 / 0$ \\
\hline Pretoria & $-\mathrm{h}$ & o & $+\mathrm{h}$ & -- & o & - & + & + & $0 /-1$ \\
\hline Nairobi & - & oh & - & o & o & o & - & $-\mathrm{h}$ & $-\mid-4$ \\
\hline Dar es Salaam & o & $-\mathrm{h}$ & - & -- & $\mathrm{oH}$ & -- & - & - & $--/-8$ \\
\hline Maputo & - & - & - & oh & $-\mathrm{H}$ & -- & - & $-\mathrm{h}$ & $--/-8$ \\
\hline Luanda & o & -- & -- & o & -- & o & - & $--h$ & $-\mid-9$ \\
\hline Average & +1 & o & -1 & +1 & o & -1 & +2 & o & $\mathrm{o} /+2$ \\
\hline
\end{tabular}

SOURCE: BASED ON EIU $(2011,31)$. THE LAST COLUMN GIVES THE ASSESSMENT BY EIU/ SIEMENS (++ TO --) AND MY OWN CALCULATION OF THE NUMBER OF PLUSSES AND MINUSES GIVEN; THE CITIES APPEAR IN ORDER OF BEST OVERALL PERFORMANCE

South African cities surpassing all other cities by far (although mainly based on coal), but on the other hand also reflects efforts to address the so-called carbon footprint, where Cape Town is the continent's pioneer, but examples given for Pretoria, Accra and Lagos (see LASE PA website) also show that there are serious attempts to develop solar and wind energy sources, as well as to use the opportunities that carbon credit schemes give to lower carbon emissions. As the first African metropolis, Cape Town launched its Integrated Environmental Policy in 2003 and this was followed by a climate change strategy in 2006, while the Cape Town Energy and Climate Change Plan was launched in 2011 (City of 
Cape Town, 2011). The city also took an initiating role in bringing African cities into the 'Compact of Mayors' that was launched in June 2016 (See Global Covenant of Mayors for Climate \& Energy website).

For land use, the main example that was highlighted dealt with the impressive attempts of the Johannesburg Development Agency (which started in 2001) to combine urban renewal, inner-city regeneration, transport improvements and better security. These have attracted many private investors and led to the launch of a large number of initiatives in the form of public-private collaborations (See Johannesburg Development Agency's website). Other examples of land use improvement given are a major reforestation effort around Addis Ababa as well as the renewal of the city's parks, urban agriculture initiatives in Casablanca, the green line project to establish a perimeter forest around the Nairobi National Park and attempts to revitalise Swahili building styles in Dar es Salaam.

For transport issues, Cairo was chosen to highlight a combination of efforts to deal with heavy congestion problems on the city's roads. This combines a major extension of the metro system, changing buses to ones that use compressed natural gas, and a carbon finance vehicle scrapping and recycling project to replace old taxis. Additional smaller highlights were given regarding the Johannesburg-Pretoria high-speed rail link, the light rail project in Tunis, together with the creation of rapid bus corridors, and finally Lagos's publicprivate partnership to develop rapid transit buses.

Waste management gets considerable attention. The major highlight is the way Lagos changed a very dilapidated system to a much more effective approach, through the creation of a new Lagos Waste Management Authority and its 'waste-to-wealth programme' (see the LAWMA website). With regard to Cape Town the report shows the importance of waste separation initiatives, an integrated waste exchange website, and the city's Smart Living Handbook. For Maputo it shows the way that the city has introduced waste management into its informal settlements, for Alexandria a new mercury waste processing plant, and for Durban the way that the city has started to support informal waste pickers.

Water and sanitation issues were separately judged, but the highlights combined them. Seven approaches were highlighted. Accra, with its strategic planning for urban water management and its 2030 vision for improved sanitation, Alexandria with its attempts to reduce water intake from the River Nile ('Switch urban water'), Dar es Salaam with its campaign for water education and Maputo for its city-wide sanitation strategy got the most attention. But Cairo's rehabilitation project for water and sanitation in the old city, Casablanca's private 
contractor to manage the city's water and sanitation, and Durban's sewage education programme were also mentioned.

Air pollution received some attention in the scores: in five of the 15 African cities that were compared, air quality was below world average levels, despite the fact that the major reason for bad air quality —industrial pollution and vehicle emissions-is (still) a less prominent problem in Africa than elsewhere in the world.

Finally, the issue of environmental governance received (very) positive scores in Accra and in the three South African cities that were part of the comparison. Major highlights were given for Durban and a minor one for Accra, but also for three cities with (very) negative overall assessments and also with negative assessments for environmental governance (Luanda, Maputo and Nairobi), probably to show that not all is lost. Durban's case is the most interesting one. The city introduced its comprehensive 'Imagine Durban' approach, ${ }^{2}$ with a lot of involvement from civil society and citizen organisations. It also formulated goals to become a zero-waste city in 2020 and a carbon neutral city by 2050. For Accra the report mentions the greenhouse gas emission identification efforts made in order to prepare for a climate change mitigation policy. Despite its negative position on the overall assessment scores, Luanda was highlighted as an example due to the establishment of an environmental database focusing on the city (supported by the African Development Bank) ${ }^{3}$, as was Maputo for its environmental education programme in schools (with emphases on tree planting and beach cleaning approaches), and finally Nairobi, where the government was working on an online approach to enable citizens to monitor their water and energy consumption (see for example, World Bank, 2015). Collaborations/Networks with African Participation

The institutional 'landscape' for sustainable city collaboration in Africa, and with other parts of the world, is quite complicated. One organisation that has been active since 1990 is ICLEI, the International Council for Local Environmental Initiatives. Since 2012 it has had a separate Africa ICLEI Committee and

2 See ASSAF's website: http://www.assaf.org.za/files/2010/04/Imagine-Durban-LTDF-2009.pdf

3 See EIU (2011), and more particularly the Green City Index on Luanda: https://www.siemens .com/entry/cc/features/greencityindex_international/all/en/pdf/luanda.pdf (accessed on 3 May 2018). 
there is also an African office in Cape Town (the organisation's World Secretariat is in Bonn). According to the Council's website, 74 municipalities in Africa from a total of 18 African countries have joined, and 19 of these are 'profiled members' (plus two local government associations) from a total of 12 African countries ${ }^{4}$. South Africa is by far the most active country in this network, with eight cities participating as profiled members, including Johannesburg, Durban and Pretoria. Of the other megacities in Africa (> two million inhabitants, see Table 2) Dakar and Addis Ababa are 'profiled members' and Cape Town, Dar es Salaam, Kampala, Lagos and Port Elizabeth/Nelson Mandela Bay are ordinary members.

Another relevant global network is UCLG Africa (United Cities and Local Governments, Africa Section) with its headquarters in Dakar. ${ }^{5}$ Together with ICLEI it partnered with UN-Habitat to produce the 'State of the African City' report of 2014 (UN-Habitat, 2014). The organisation's website gives access to all relevant national associations of local government, including the important South African Association of Local Government Authorities ${ }^{6}$ and the Association des Maires du Sénégal (AMS). ${ }^{7}$ Its focus on sustainability is rather limited, though, with the exception of the attention paid to informal settlements, and their environmental problems, in the 'Know Your City' programme, with a special focus on Ouagadougou and Lusaka.

A third network is Rockefeller Foundation's 100 Resilient Cities (http:// www.10oresilientcities.org), with eleven participants from Africa, including a few surprising ones: Accra, Addis Ababa, Cape Town, Dakar, Durban, Enugu (in Nigeria), Kigali, Lagos, Luxor, Nairobi and Paynesville (in Liberia). On its website, the Rockefeller project states: 'As of May 2016, the 100 Resilient Cities network has reached 100 members. The new group of cities spans five continents and is diverse in both its makeup and the challenges the cities face. The 100 Resilient Cities Challenge is the application process by which cities join our network. $100 R C$ selected a first group of 32 cities in December 2013, a second group of 35 in 2014, and its final round of winners in May 2016 [including six new 'winners' from Africa]. Members of the 100 Resilient Cities team and a panel of expert judges reviewed over 1,00o applications from prospective cities. The judges looked for innovative mayors, a recent catalyst for change, a history of building partnerships, and an ability to work with a wide range

4 See ICLEI's African Secretariat website: http://africa.iclei.org.

5 See UCLG Africa website: http://www.uclga.org.

6 See SALGA's website: http://www.salga.org.za.

7 See UCLG Africa website: http://www.afriquelocale.org/fr/ams. 
of stakeholders'. Africa is relatively well represented now, after North America (with 31 member cities), Asia (with 20) and Europe (with 17).

A fourth network, also with a major input from the USA (funded by three philanthropic organisations), but with offices in New York, London and Rio de Janeiro, is $\mathrm{C}_{40}$ (http://c4o.org), for so-called climate action cities. It is connected to the Clinton Climate Initiative. Nine African megacities are part of this network, and there is a separate directorate for Africa within $\mathrm{C}_{40}$, directed by economist and 'environmental diplomat' Hastings Chikoko, from Malawi. The participating African cities (so far) are Cairo, Accra, Lagos, Addis Ababa, Nairobi, Dar es Salaam, Johannesburg, Durban and Cape Town. Johannesburg plays a key role.

Canada has launched its own support programme for sustainable cities (http://sustainablecities.net/), based in Vancouver. It has three African partner cities: Dakar in Senegal, with three projects, Dar es Salaam with two projects, and Durban in South Africa, also with two projects. These are all part of the so-called P LUS network for sustainability learning.

The Fondation Africaine pour la Gestion Urbaine, a network that started in Senegal and that was based at the Institut Africain de Gestion Urbaine (IAGU) in Dakar (IAGU, 2008), mainly deals with cities in French-speaking Africa, with projects in Dakar, Thiès and Pikine in Senegal, but also (with an emphasis on urban agriculture) in Burkina Faso (Bobo Dioulasso), Benin (Porto Novo), Rwanda (Kigali) and Mauritania (Nouakchott). With the exception of Dakar, no other African megacity (defined as having agglomerations of more than two million inhabitants) participates.

In preparation for the climate conference in Paris in 2015 a lot of effort was mobilised to stimulate debates about Africa's sustainability issues, ${ }^{8}$ and part of it was focused on issues of urban sustainability (see Dago, 2014). To create villes durables (sustainable cities) the focus should be on six elements, according to this approach: connect health and the environment, stimulate resilience, emphasise popular participation (through sensibilisation (sensitization)), diversify finances to fund green initiatives, create stakeholder platforms (cerveaux collectifs), and adapt and readjust for every city, connecting environmental, social, economic and cultural specificities.

In 2016, partly as a response to the climate conference in Paris, many mayors of the world formed the Compact of Mayors (see Global Covenant of Mayors for Climate \& Energy website). For all participating cities, the organisation's website shows a map of the city, the name of the current mayor, mostly the current population figure, and what the city has done in terms of commitment,

8 See the AfriqueCroissanceVerte website: https://afriquecroissanceverte.com/. 
inventory, target formulation and planning for climate mitigation and adaptation. It is the intention to also add data about greenhouse gas emissions and sectoral composition for each city. Almost all African cities are still in the 'commitment phase', but Cape Town and Durban have completed all phases, and one can download the climate adaptation and climate action plans for these cities. The Compact of Mayors has so far managed to connect to 18 of Africa's multi-million agglomerations and to 32 other African cities.

With growing privatisation and many public-private partnerships in environmental management it is also relevant to mention a site that provides a global overview of environmental companies, including of more than 1,500 companies working in Africa: Environmental XPRT. ${ }^{9}$ The large majority of these companies have their headquarters elsewhere in the world, but they also have an office, or are distributors, in Africa, and particularly in South Africa. But there are also African companies and NGOs on the list (like the Water and Sewerage Company in Nairobi, and the Waste Management Society of Nigeria, based in Port Harcourt).

If we look at all those initiatives and focus on Africa's multi-million agglomerations it is obvious that some of those urban areas are leading in many initiatives, and others are invisible (see Table 6.5).

TABLE 6.5 Summary of online networks/assessments of participating African megacities

\begin{tabular}{|c|c|c|c|c|c|c|}
\hline $\begin{array}{l}\text { Urban } \\
\text { agglomeration }\end{array}$ & EIU & $\mathrm{C}_{40}$ & Rockefeller & SSnet & $\begin{array}{l}\text { ICLEI } \\
\text { [/UCLG] }\end{array}$ & Compact \\
\hline Lagos & + & + & + & & + & + \\
\hline Cairo & + & + & & & & \\
\hline $\begin{array}{l}\text { Johannesburg/ } \\
\text { Pretoria }\end{array}$ & ++ & + & & & + & + \\
\hline Kinshasa & & & & & & + \\
\hline Luanda & + & & & & & \\
\hline \multicolumn{7}{|l|}{ Khartoum } \\
\hline Dar es Salaam & + & + & & + & + & \\
\hline Nairobi & + & + & + & & & + \\
\hline Alexandria & + & & & & & \\
\hline
\end{tabular}

9 See Environmental XPRT, Environmental Industry Companies in Africa webpage : https:// www.environmental-expert.com/companies/location-africa (accessed on 3 May 2018). 
TABLE 6.5 Summary of online networks/assessments of participating African megacities (cont.)

\begin{tabular}{llllll}
\hline $\begin{array}{l}\text { Urban } \\
\text { agglomeration }\end{array}$ & EIU & $\mathrm{C}_{40}$ & Rockefeller & SSnet & ICLEI \\
{$[/$ UCLG $]$} & Compact
\end{tabular}

\begin{tabular}{|c|c|c|c|c|c|c|}
\hline Abidjan & & & & & & + \\
\hline Accra & + & + & + & & & + \\
\hline Casablanca & + & & & & & \\
\hline Cape Town & + & + & + & & + & + \\
\hline \multicolumn{7}{|l|}{ Kano } \\
\hline \multicolumn{7}{|l|}{ Algiers } \\
\hline Addis Ababa & + & + & & & + & + \\
\hline Dakar & & & + & + & + & + \\
\hline Durban & + & + & + & + & + & + \\
\hline \multicolumn{7}{|l|}{ Ibadan } \\
\hline Kampala & & & & & + & + \\
\hline \multicolumn{7}{|l|}{ Bamako } \\
\hline \multicolumn{7}{|l|}{ Abuja } \\
\hline \multicolumn{7}{|l|}{ Douala } \\
\hline Yaoundé & & & & & & + \\
\hline \multicolumn{7}{|l|}{ Kumasi } \\
\hline Tunis & + & & & & & \\
\hline Harare & & & & & & + \\
\hline Lusaka & & & & & {$[+]$} & \\
\hline \multicolumn{7}{|l|}{ Antananarivo } \\
\hline \multicolumn{7}{|l|}{ Conakry } \\
\hline Maputo & + & & & & & \\
\hline Ouagadougou & & & & & {$[+]$} & \\
\hline Port Harcourt & & & & & & \\
\hline
\end{tabular}

SOURCE: AUTHOR'S OWN ANALYSIS OF THE VARIOUS WEBSITES MENTIONED IN THE TEXT. CITIES ARE LISTED IN DESCENDING ORDER OF NUMBER OF INHABITANTS, FOLLOWING THE ORDER USED IN TABLE 6.2 
UN-Habitat is the institutional flagship organisation within the UN system dealing with urban issues. It is based in Nairobi and can be expected to pay special attention to Africa. Since 2008 it has published three overviews of the state of Africa's cities (UN-Habitat 2008, 2010 and 2014). In 2008, the report was published together with the United Nations Commission for Africa (UNECA), the United Nations Environmental Programme (UNEP) and the International Development Research Centre (IDRC) in Canada. In 2010 only UNEP stayed as a partner, and in 2014 the partnership changed to include both ICLEI and UCLG. In 2008, urban environmental challenges were one of six major themes. In 2010, the report had a very geographical set up: with sections on the social geography of urbanisation, the economic geography of cities, the geography of urban land markets and the geography of climate change. The report published in 2014 explicitly deals with urban sustainability in its sections on social and environmental challenges. In these reports UN-Habitat's strongly geographical outlook means a strong emphasis on broad geographical and thematic inclusiveness, and a growing emphasis on the combination of sustainability issues and social inclusion issues, particularly in sections regarding vulnerability to climate change and in those dealing with the health risks of pollution and waste management. In the UN-Habitat 2014 publication there are many references to the recent wave of 'climate change and cities' publications, including Rosenzweig et al. (2011). Another work referred to is the ICLEI study authored by Kemp et al. (2011): Sub-Saharan African Cities: A Five-City Network to Pioneer Climate Adaptation Through Participatory Research \& Local Action. These authors (some of them biologists) were based in Cape Town when they carried out the study. Cartwright et al. (2012) published another relevant study about Cape Town itself in 2012. One of its authors is a leading urban geographer in South Africa, Sue Parnell. Some of these studies connect issues of climate change with urban food security, as does the work of Frayne et al. (2013). Bruce Frayne and Gina Ziervogel are geographers, connected to the University of Cape Town. Sustainable city initiatives in South Africa have become an important, if not dominant, element in Africa's sustainability efforts, and we will therefore continue with a brief focus on South Africa.

In South Africa, the South African Cities Network started in 2002, and has so far published four reports about 'the state of South African cities' (SACN). On its 
website, the Network states: 'The South African Cities Network (SACN) is an established network of South African cities and partners that encourages the exchange of information, experience and best practices on urban development and city management. As both a research source and a catalyst for debate, the SACN covers the full scope of the urban management process, under the following thematic areas: city development, inclusive cities, sustainable cities, well-governed cities and productive cities'. And under the heading of 'sustainable cities' there are four major topics: sustainable energy, improving waste management, improving water management, and mitigating climate change effects. To date, there have been four 'state of South African cities' reports (see SACN, 2004, 2006, 2011 and 2016). From the start 'sustainable cities' was a major and recurrent theme. In 2016, there was also a 'People's Guide'.

The chapter about sustainable cities in the 2016 SACN document about South African Cities (SACN, 2016) was written by Sandiswa Tshaka, an energy and climate change expert who previously worked for the Danish Embassy, and by Gillian Maree, who had professional training as a spatial planner in the Netherlands and who has worked to support spatial economic policy and strategic environmental planning in South Africa. The key messages in this chapter come very close to a fully holistic approach: "The typical South African city is growing in a resource-intensive way and suffers from inefficiencies across all sectors (energy, food, water, waste and transport). The current silo approach to planning and delivery is inefficient and increases risks of exclusion. Cities should pursue spatial transformation, which encourages compact cities and sustainable neighbourhoods that value natural and open spaces. Sustainability and growth are interdependent, and so sustainability must be fundamentally embedded in a city's development paradigm, and not just in its long-term visions and strategies. Cities need to tackle resource efficiency aggressively' (SACN, 2016, 12).

One of the leading think tanks addressing Africa's urban and urban environmental issues is firmly connected to geography and urban planning: the University of Cape Town's African Centre for Cities (ACC). Many of its research projects and publications deal with Cape Town itself, but there is also a growing connection to other cities in southern Africa, cities in Africa more generally, and cities elsewhere, with a major attempt to connect African and Asian experiences. The ACC is a central player in major academic and think tank networks concerned with sustainable cities with a focus on Africa: UrbanAfrica.net ('communicating about African cities'), the Association of African Planning Schools, ${ }^{10}$

10 See the Association of African Planning Schools (AAPS) website: http://www.africanplan ningschools.org.za/. 
the African Urban Research Initiative ${ }^{11}$ and the African Food Security Network. ${ }^{12}$ The ACc's director, Edgar Pieterse (with a PhD from the London School of Economics) holds the South African Research Chair in Urban Policy at UCT, but is also one of four African members of the Sustainable Development Solutions Network ${ }^{13}$ (sDSN; based in Paris and New York as the UN's think tank for sustainable cities).${ }^{14}$ Among Pieterse's most influential publications are City futures: Confronting the crisis of urban development (Pieterse, 2008) and 'The "right to the city": institutional imperatives of a developmental state' (Parnell and Pieterse, 2010). A more recent work by Parnell and Pieterse is concerned with Africa's urban revolution (Parnell and Pieterse, 2014). South Africa's leading role in Africa's sustainable cities 'movement' is very much assisted by the important role think tanks such as the AAC play, but also by the way metropolitan governments in South Africa use information databases to make informed choices on where to prioritise investments in better environmental services (see Sutherland et al. 2015).

\section{$7 \quad$ Online Sustainability Representations and Social Inclusion}

Looking at the various Internet representations of sustainable cities initiatives in Africa presented in this chapter one cannot escape the impression that most focus on well-to-do neighbourhoods that are part of planned city expansions or those developed by city development or housing companies. Also, demands for 'better environmental care' often come from middle-class (or upper-class) activists, with limited attention paid to the living conditions and major environmental issues in shanty towns and among the urban poor. As there is a

11 More information on the African Urban Research Initiative (AURI) on http://www.african centreforcities.net/programme/knowledge-networks/african-urban-research-initiative.

12 See the African Food Security Urban Network (AFSUN) website: http://www.afsun.org.

13 Other African members of the SDSN Network are Martin Oteng-Ababio, geographer at the University of Ghana at Legon, climate change expert Debra Roberts of the Ethekwini Municipality (Durban), and urban planner Rafael Tuts of UN-Habitat (with a degree as an architectural engineer from the University of Leuven, Belgium). The UN started this initiative in 2012 with a goal to "mobilize global scientific and technological expertise to promote practical problem solving for sustainable development, including the design and implementation of the Sustainable Development Goals (SDGs)" (see the SDSN website, i.e. http://unsdsn.org/about-us/vision-and-organization/). Martin Oteng-Ababio's most cited work is about waste management in Accra; see Grant and Oteng-Ababio (2012); Oteng-Ababio et al. (2013).

14 See the Thematic Network 'Sustainable Cities: Inclusive, Resilient, and Connected': http://unsdsn.org/what-we-do/thematic-networks/sustainable-cities-inclusive-resilient -and-connected (accessed on 3 May 2018). 
clear tendency for the urban poor to live in the most risky and vulnerable areas (in particular, marshy and flood-prone areas near coasts are noteworthy: areas where ever more urban poor start their urban lives), attention to urban sustainability should highlight these areas and people, but this often does not happen, and is not the highest priority for eager city planners and city administrators who want their cities to shine on prestigious websites. . The growing attention being paid to climate change (Bicknell et al., 2009; Carmin et al., 2012; Simon, 2013; Dodman et al., 2015; Wisner et al., 2015) and the inclusion of 'sustainable cities and communities' as Goal 11 of the Sustainable Development Goals might change that bias: the highest social vulnerability to the effects of climate change can be found in the neighbourhoods with the most problematic environmental conditions. Particularly in coastal cities many informal settlements can be found in high-risk locations with regard to storms, floods and disease outbreaks. Cities like Durban and Cape Town can probably be seen as useful and early cases of experimentation where a holistic approach to sustainability has been combined with sincere attention to social inclusiveness from scholars and in some cases also from urban planners, although a lot more could have been done and could be done (see, e.g., Roberts and Nicci (2002); Sutherland et al. (2015) for Durban, and Cartwright et al. (2012) for Cape Town).

\section{Conclusion}

Although recently many initiatives have attempted to stimulate African cities to develop policies for more sustainable urban development, the geographical coverage of those initiatives is by no means complete, and websites devoted to these 'sustainable city initiatives' in Africa show a very unbalanced picture, with some South African and some North African cities getting a lot of attention, together with cities like Accra, Lagos and Nairobi, but with other cities enjoying much less, particularly those outside anglophone countries. In terms of thematic coverage for African cities as a whole, the websites show that all major aspects are covered, with particular attention given to waste management and water management. However, for almost all individual cities (except for Cape Town and Durban), there is no 'holistic approach', and the institutional set-up of most metropolitan regions does not stimulate a holistic approach to integrated environmental management. And if we look at the third aspect of 'inclusion', social inclusiveness, the Internet representation of successful urban sustainability projects seems to favour well-to-do neighbourhoods and new neighbourhoods. We recommend that policymakers become more inclusive, and that scholars - as well as scholarly informed international agencies 
working to stimulate urban sustainability in Africa-become more focused on the three types of inclusion outlined in this chapter: wider geographical coverage, a more holistic approach, and attention given to the social inclusiveness of approaches and effects. We also recommend much more active participation by the urban poor, and their organisations where those exist. To enable such an approach, urban planners, environmental scientists and urban geographers should devote more energy to liaising with urban anthropologists, and others for whom participatory observation, and long-term involvement with and among the urban poor, is a more natural habitus than for many current urban sustainability experts.

\section{Acknowledgements}

An earlier version of this chapter was published as a working paper on the website of the African Studies Centre Leiden (www.ascleiden.nl) as 'Sustainable City initiatives in Africa and comparison with the oursus approach'. An outline was presented at the IGU Congress in Beijing, on 22 August 2016, and benefited from comments by Qiu Li and Brij Maharaj, as well as other people participating at the conference. Additional discussions took place during the annual conference of the Netherlands Association of African Studies, in 2017, and during the 7 th European Conference on African Studies (ECAS) in Basel in 2017 .

\section{References}

Bicknell, J., D. Dodman and D. Satterthwaite, eds. (2009) Adapting Cities to Climate Change: Understanding and addressing the development challenges (London: Earthscan).

Carmin, J., I. Anguelovski and D. Roberts (2012) 'Urban climate adaptation in the global south planning in an emerging policy domain' Journal of Planning Education and Research 32(1), pp. 18-32, DOI: 10.1177/0739456X11430951.

Cartwright, A., S. Parnell, G. Oelofse and S. Ward (eds.) (2012) Climate change at the city scale: Impacts, mitigation and adaptation in Cape Town (London, New York: Routledge).

City of Cape Town (2011) Moving Mountains. Cape Town's Action Plan for Energy and Climate Change. (City of Cape Town: Cape Town) http://resource.capetown.gov .za/documentcentre/Documents/Graphics\%2oand\%2oeducational\%2omaterial/ Moving_Mountains_Energy+CC_booklet_2011-11.pdf (accessed on 3 May 2018). 
Cohen, B. (2006) 'Urbanization in developing countries: current trends, future projections and key challenges for sustainability', Technology in Society 28(1), pp. 63-80, DOI: 10.1016/j.techsoc.2005.10.005.

Dago, S. (2014) ' 7 exigences pour les villes durables en Afrique de l'Ouest', Afriquecroissanceverte, https://afriquecroissanceverte.com/2014/10/02/villes-durables-en-afrique-de -louest-7-exigences-pour-en-faire-une-realite/ (accessed on 3 May 2018).

Dietz, T., D. Foeken, S. Soeters and N. de Vink (2012) Africa: from a continent of states to a continent of cities (Leiden: African Studies Centre), http://hdl.handle .net $/ 1887 / 20017$.

Dodman, D., K. Soltesova, D. Satterthwaite and C. Tacoli (2015) Understanding the Assessment and Reduction of Vulnerability to Climate Change in African Cities: A Focus on Low-Income and Informal Settlements, Série grise (Paris: Agence Française de Développement), https://www.afd.fr/en/understanding-assessment-and-reduction -vulnerability-climate-change-african-cities-focus-low-income-and-informal-set tlements (accessed on 3 May 2018).

EIU (Economist Intelligence Unit) (2011) African Green City Index. Assessing the environmental performance of Africa's major cities. (München: Siemens A.G.), https:// www.siemens.com/entry/cc/features/greencityindex_international/all/en/pdf/ report_africa_en.pdf (accessed on 3 May 2018).

Frayne, B., C. Moser and G. Ziervogel (eds.) (2013) Climate change, assets and food security in Southern African cities (London, New York: Routledge).

Grant, R., and M. Oteng-Ababio (2012) 'Mapping the invisible and real "African" economy: urban e-waste circuitry' Urban Geography 33(1), pp. 1-21, DOI: 10.2747/ 0272-3638.33.1.1.

Hall, T., and H. Barrett (2012) Urban Geography, 4th ed. (London \& New York: Routledge). Institut Africain de Gestion Urbaine (IAGU) (2008) 2004-2007 Partenariats pour des villes durables (Dakar: IAGU), http://www.iagu.org/ (accessed on 3 May 2018).

Kaplan, D.H. and S. Holloway (2014) Urban Geography (New York: Wiley Global Education).

Kemp, L., L. Fairhurst, P. Rowswell and T. Quayle (2011) Sub-Saharan African Cities: A Five-City Network to Pioneer Climate Adaptation Through Participatory Research \& Local Action. (Local Governments for Sustainability ICLEI: Cape Town), http:// resilient-cities.iclei.org/fileadmin/sites/resilient-cities/files/Images_and_logos/ Resilience_Resource_Point/ICLEI_Africa_5_City_Adaptation_Network_Workshop _Report_Final4_web_size.pdf (accessed on 3 May 2018).

Knox, P.L. and L. McCarthy (2012) Urbanization: an introduction to urban geography. (Boston: Pearson).

Oteng-Ababio, M., J.E. Melara Arguello and O. Gabbay (2013) 'Solid waste management in African cities: Sorting the facts from the fads in Accra, Ghana', Habitat International 39, pp. 96-104, DOI: 10.1016/j.habitatint.2012.10.010. 
Pacione, M. (2009) Urban geography, a global perspective, $3^{\mathrm{d}}$ ed., (London, New York: Routledge).

Parnell, S., and E.A. Pieterse. (2014) Africa's urban revolution (London: Zed Press).

Parnell, S. and E.A. Pieterse (2010) 'The 'Right to the City': Institutional Imperatives of a Developmental State', International journal of urban and regional research, 34(1), pp. 146-162, DOI: 10.1111/j.1468-2427.2010.00954.x.

Pieterse, E.A. (2008) City futures: Confronting the crisis of urban development (London: Zed Books).

Roberts, D. and D. Nicci (2002) 'Durban's Local Agenda 21 Programme: Tackling Sustainable Development in a Post-Apartheid City', Environment and Urbanization, 14(1), pp.189-201, DOI: 10.1177/095624780201400116.

Rosenzweig, C., W. Solecki, S Hammer and S. Mehrotra (eds.) (2011) Climate Change and Cities: First Assessment Report of the Urban Climate Change Research Network (Cambridge: Cambridge University Press).

SACN (South African Cities Network) (2016) State of African Cities Report 2016 (Braamfontein: SACN), http://www.sacities.net/state-of-cities-reporting/socr-2016 (accessed on 3 May 2018).

SACN (2011) State of African Cities Report 2011 (Braamfontein: SACN), http://www.saci ties.net/state-of-cities-reporting/45 (accessed on 3 May 2018).

SACN (2006) State of African Cities Report 2006 (Braamfontein: SACN), http://www .sacities.net/state-of-cities-reporting/44 (accessed on 3 May 2018).

SACN (2004) State of African Cities Report 2004 (Braamfontein: SACN), http://www .sacities.net/state-of-cities-reporting/43 (accessed on 3 May 2018).

Simon, D. (2013) 'Climate and environmental change and the potential for greening African cities', Local Economy, 28(2), pp. 203-217, DOI: 10.1177/0269094212463674.

Sutherland, C., D. Scott and M. Hordijk (2015) 'Urban Water Governance for More Inclusive Development: A Reflection on the "Waterscapes" of Durban', South Africa European Journal of Development Research, 27(4), pp. 488-504, http://hdl.handle .net/11245/1.487646.

UN-Habitat (United Nations Human Settlements Programme) (2014) The State of African Cities 2014. Reimagining Sustainable Urban Transitions (Nairobi: UN-Habitat), http://unhabitat.org/books/state-of-african-cities-2014-re-imagining-sustainable -urban-transitions/ (accessed on 3 May 2018).

United Nations Department of Economic and Social Affairs (2014) World Urbanization Prospects (Revision) (New York: United Nations), https://esa.un.org/unpd/wup/ (accessed on 3 May 2018)

UN-Habitat (2010) The State of African Cities 2010. Governance, Inequality and Urban Land Markets (Nairobi: UN-Habitat), https://www.citiesalliance.org/sites/cit iesalliance.org/files/UNH_StateofAfricanCities_2010.pdf (accessed on 3 March 2018). 
UN-Habitat (2008) The State of African Cities 2008. A framework for addressing urban challenges in Africa (Nairobi: UN-Habitat), http://unhabitat.org/books/the-state-of -the-african-cities-report-2008/ (accessed on 3 March 2018).

Wisner, B., M. Pelling, A. Mascarenhas, A. Holloway, B. Ndong, P. Faye, J. Ribot and D. Simon (2015) 'Small Cities and Towns in Africa: Insights into Adaptation Challenges and Potentials', in S. Pauleit, G. Jorgensen, S. Kabisch, P. Gasparini, S. Fohlmeister, I. Simonis, K. Yeshitela, A. Coly, S. Lindley, W.J. Kombe (Eds) Urban Vulnerability and Climate Change in Africa, a multidisciplinary approach (Dordrecht: Springer), pp. 153-196, DOI: 10.1007/978-3-319-03982-4_5.

World Bank (2015) Open Energy Data Assessment Nairobi, Kenya (Washington D.C.: World Bank), http://opendatatoolkit.worldbank.org/docs/odra/odra_energy-nairo bi.pdf (accessed on 3 May 2018).

\section{Webpages}

ASSAF (Academy of Science of South Africa), http://www.assaf.org.za/files/2010/04/ Imagine-Durban-LTDF-2009.pdf (accessed on 29 May 2018).

AAPS (Association of African Planning Schools), http://www.africanplanningschools. org.za (accessed on 3 May 2018).

ACC (African Centre for Cities), https://www.africancentreforcities.net (accessed on 3 May 2018).

AfriqueCroissanceVerte, https://afriquecroissanceverte.com (accessed on 3 May 2018).

AFSUN (African Food Security Urban Network), http://www.afsun.org (accessed on 3 May 2018).

Brinkhoff T., Major Agglomerations of the World, http://www.citypopulation.de (accessed on 3 May 2018).

C40 cities, http://www.c40.org (accessed on 3 May 2018).

Global Covenant of Mayors for Climate \& Energy, http://www.compactofmayors.org/ cities/ (accessed on 3 May 2018).

Heilig, K, http://www.demographics.at (accessed on 3 May 2018).

ICLEI (International Council for Local Environmental Initiatives), http://www.iclei .org/ (accessed on 3 May 2018).

JDA (Johannesburg Development Agency), http://www.jda.org.za (accessed on 3 May 2018).

LASEPA (Lagos State Environmental Protection Agency), http://lasepa.gov.ng/, (accessed on 3 May 2018).

LAWMA (Lagos Waste Management Authority), http://www.lawma.gov.ng, (accessed on 3 May 2018).

Rockefeller Foundation, 100 Resilient Cities, http://www.10oresilientcities.org. 
SALGA (South African Local Government Association), http://www.salga.org.za (accessed on 3 May 2018).

SDSN (UN Sustainable Development Solutions Network), http://unsdsn.org (accessed on 3 May 2018).

Statistics Times (2015), List of Countries by Population, http://statisticstimes.com/popu lation/countries-by-population.php (accessed on 3 May 2018).

Sustainable Cities International (SCI), http://sustainablecities.net (accessed on 3 May 2018).

United Cities and Local Governments, Africa Section, http://www.uclga.org (accessed on 3 May 2018).

UrbanAfrica.net, http://www.urbanafrica.net (accessed on 3 May 2018).

World Bank Data, Urban Population, https://data.worldbank.org/indicator/SP.URB .TOTL.IN.ZS (accessed on 3 May 2018).

World Bank Data, Sub-Saharan Africa regional aggregate, https://data.worldbank.org/ region/sub-saharan-africa (accessed on 3 May 2018). 